DOI: https://doi.org/10.15407/techned2018.06 $\leq \underline{073}$

\title{
EFFICIENCY OF REGENERATIVE BRAKING IN ENERGY SUPPLY SYSTEMS WITH ELECTRIC REGULATED DRIVES
}

Journal

Publisher

ISSN

Issue

Pages
Tekhnichna elektrodynamika

Institute of Electrodynamics National Academy of Science of Ukraine 1607-7970 (print), 2218-1903 (online)

No 6, 2018 (November/December)

$73-76$

\section{Authors}

\section{G.G. Zhemerov $^{1 *}$, N.A. Ilina ${ }^{1 * \star}$, A.V. Mashura ${ }^{1}$, D.V. Tugay ${ }^{2 \star \star \star}$}

1 - National Technical University "Kharkov Polytechnic Institute",

Kirpichova str., 2, Kharkiv, 61002, Ukraine

2 - O.M. Beketov National University of Urban Economy in Kharkiv, Marshal Bazhanov str., 17, Kharkiv, 61002, Ukraine,

e-mail: tugaydmytro@gmail.com

* ORCID ID : http://orcid.org/0000-0002-3469-0121

** ORCID ID : http://orcid.org/0000-0001-5644-862X

*** ORCID ID : http://orcid.org/0000-0003-2617-0297

\section{Abstract}

Analytical formulas for calculating the maximum possible efficiency of energy supply system with electric regulated drive for three operating modes due to the direction of the energy flow in the system - direct, reverse and bi-directional are obtained. It is shown that even at high values of the energy supply system efficiency in the direct and reverse flows, at high values of the 
energy return factor, the efficiency in the bi-directional flow can be catastrophically low. Referen ces 4 , figures 3 .

Key words: power supply system, energy return factor, efficiency.

Received: 05.03 .2018

Accepted: 17.04 .2018

Published: 23.10 .2018

\section{References}

1. Nykyforov M.M., Kashtanov A.L., Kandaev V.A. Methods for assessing the potential for energy efficiency in the application of regenerative braking. Izvestiia Transsiba. 2012. No 1 (9). Pp. 72-78. (Rus)

2. Kostin N.A., Nikitenko A.V. Autonomy of recuperative braking - the basis of reliable energy-efficient recovery on the electromotive force constant current. Zaliznychnyi transport Ukrainy. 2014. No 3. Pp. 15-23. (Rus)

3. Artemenko M.Yu., Batrak L.M., Mykhalskyi V.M., Polishchuk S.Y. Analysis of possibility to increase the efficiency of three-phase four-wire power system by means of shunt active filter. $T$ ekhnichna Elektrodynamika . 2015. No 6. Pp. 12-18. (Ukr)

4. Zhemerov G., Ilina N., Tugay D. The Theorem of Minimum Energy Losses in Three-Phase Four-Wire Energy Supply System. $20162^{\text {nd }}$ IEEE International Conference on Intelligent Energy and Power Systems

2016, Kyiv, Ukraine, Pp. 52-54. DOI:

(IEPS-2016). June 07-11, https://doi.org/10.1109/IEPS.2016.7521889 
PDF 